Dept. of Animal Medicine,

Fac. Vet. Med. Assiut University.

\title{
EVALUATION OF SERUM ACTIVITY OF CPK AND AST IN REPEAT BREEDER COWS WITH CLINICAL AND SUBCLINICAL ENDOMETRITIS
}

(With One Table and 2 Figures)

\author{
By \\ GHADA A. ABOU EL-ELLA; H.A. HUSSEIN* \\ and D.R.DERAR*
}

* Dept. Theriogenology, Faculty of Veterinary Medicine, Assiut University (Received at 23/12/2008)

تقييم نشاط انزيمى ال AST, CPK فى مصل الام فى حالات الثيوع المتكرر المصاحب للاصابات السريرية والتحث السريرية لإلتهاب الجدار المبطن فيطن للرحم فى الابقار

غادة /حمد محد ابو العلا ، حسن عبل الصبور على ، ضرار رفعت ابراهيم

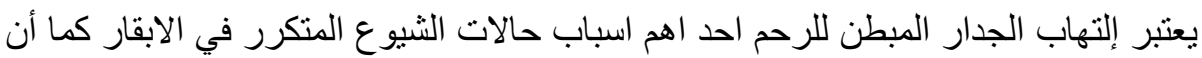

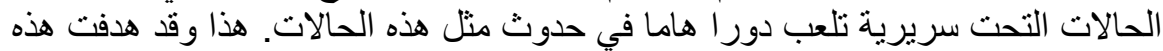

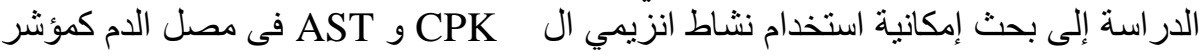

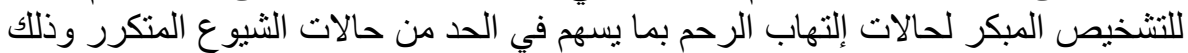

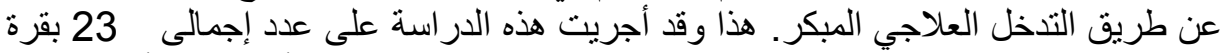

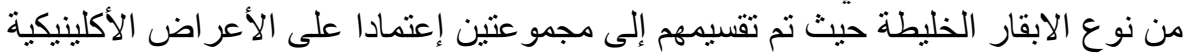

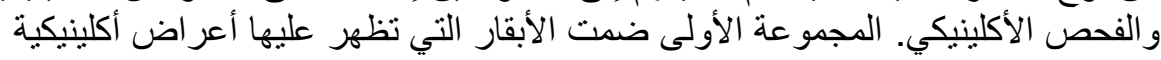

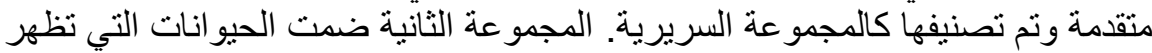

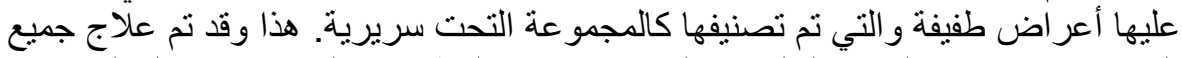

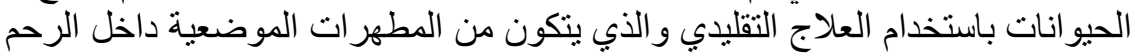

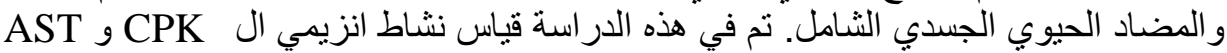

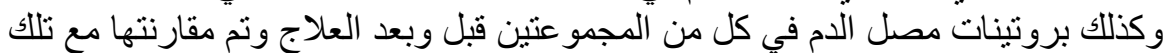

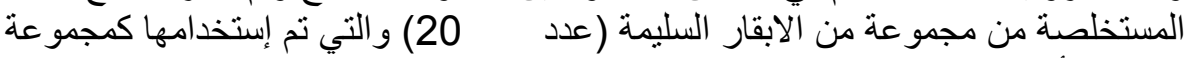

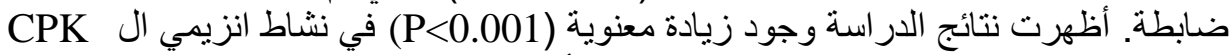

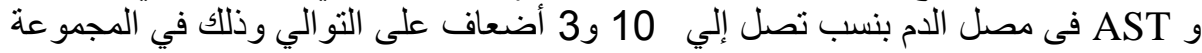

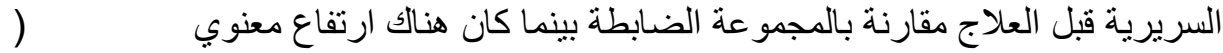

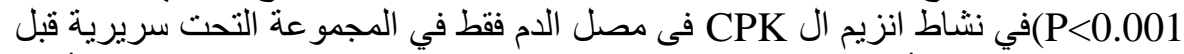

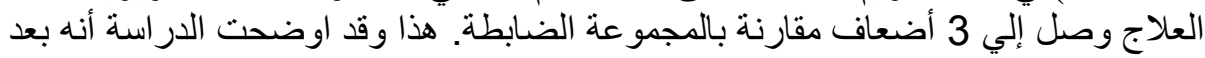

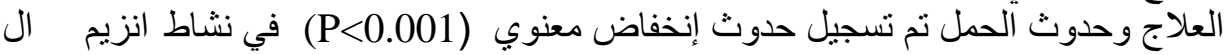


في كل من المجمو عة الأولى والثانية مقارنة بنفس المجمو عات قبل العلاج بينما نت

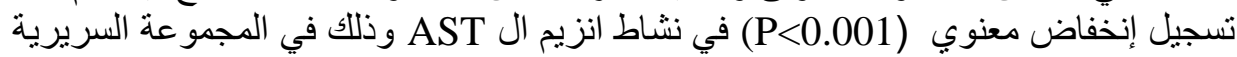

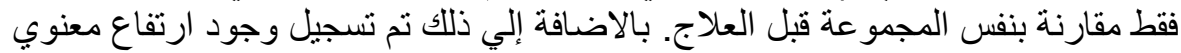

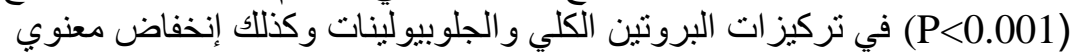

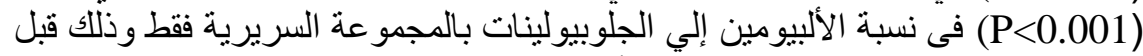

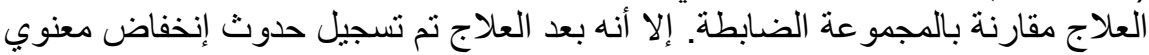
بي بـ (P<0.001)

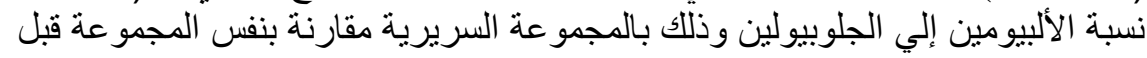

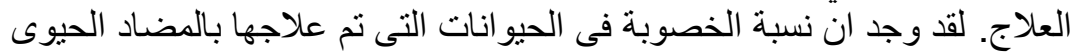

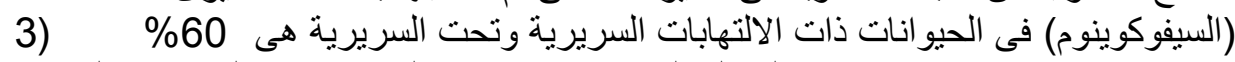

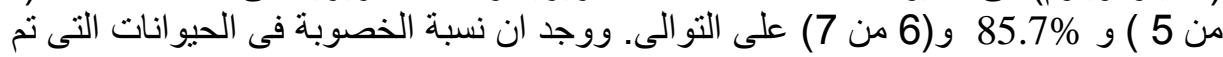

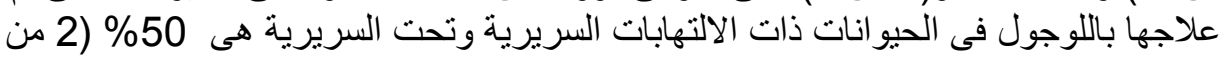

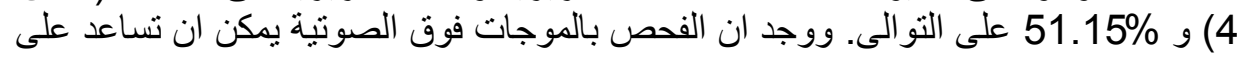

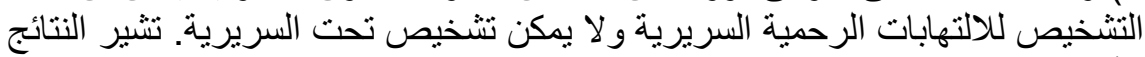

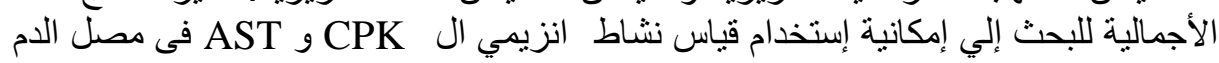

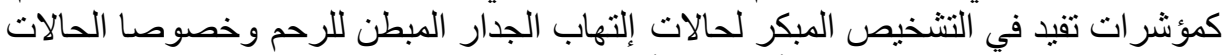

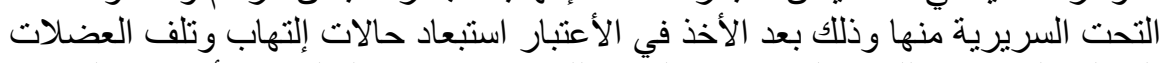

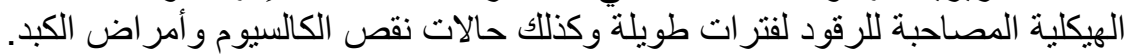

\section{SUMMARY}

Endometritis is one of the main causes of repeat breeder syndrome of cows. Sub-clinical endometritis is considered as a major contributor to the syndrome. The goal of the current study was to investigate the possible role of CPK and AST enzymes as early diagnostic parameters for detection of cows with clinical or sub-clinical endometrits and prediction of the fate of the repeat breeder cows. A total of 23 repeat breeder Holstein Friesian cows were subjected to the study. Based on clinical manifestations and the degree of uterine affections, investigated animals were subdivided into 2 groups; the severely affected cows that were assigned as the clinical endometrits group ( $\mathrm{G} 1, \mathrm{n}=9)$, and the mildly affected cows that were assigned as the sub-clinical endometritis group (G2, n=14). Five cows from $\mathrm{G} 1$ and 7 cows from $\mathrm{G} 2$ were treated using local intrauterine Cephquenome $0.5 \mathrm{gm}$ antibiotic and 4 cows from G1 and 7 cow from G2 using Lugol' Iodine 2\% (30 ml) intrauterine. The activity of CPK and AST enzymes were evaluated in both groups before and after treatment in comparison with healthy control group $(n=20)$. In addition, protein profiles of examined animals were recorded. The results of the current study revealed that, before treatment there were up to 10 folds and 3 folds significant increase $(\mathrm{P} \leq 0.001)$ in the 
activity of CPK and AST, respectively, in clinical endometritis group as compared to the control healthy group. While there was up to 3 folds significant increase $(\mathrm{P} \leq 0.001)$ only of $\mathrm{CPK}$ activity in sub-clinical endometritis group. After treatment and occurrence of conception, significant reduction $(\mathrm{P} \leq 0.001)$ of $\mathrm{CPK}$ activity in both clinical and subclinical endometritis group and AST activity in clinical endometritis group was recorded as compared to their activities before treatment. In addition, significant elevation $(\mathrm{P} \leq 0.001)$ of total proteins and globulins levels along with significant reduction $(\mathrm{P} \leq 0.001)$ of the $\mathrm{A} / \mathrm{G}$ ratio were recorded only in clinical endometritis group before treatment as compared to the healthy control group. However, after treatment, significant reduction $(\mathrm{P} \leq 0.001)$ of total proteins and globulins levels and significant elevation $(\mathrm{P} \leq 0.001)$ of $\mathrm{A} / \mathrm{G}$ ratio were evident as compared to that before treatment. It was found the after using Cephquenome the conception rate in G1 and G2 was 60\% (3 from 5 cows) and 85.7\% (6 from 7 cows) respectively. The resulted conception rate after application of Lugol' Iodine in G1 and G2 was 50\% (2 from 4 cows) and $51.14 \%$ (4 from 7 cows), respectively. In conclusion, after exclusion of recumbency-based muscular damage, hypocalcemia or liver diseases, the activity of CPK and AST enzymes can be used as a screening parameters for diagnosis of endometrits and early detection of sub-clinical cases.

Key words: CPK, AST, Total protein, endometritis, cow

\section{INTRODUCTION}

Repeat breeder (RB) is a substantial problem in cattle breeding leading to large economic losses for the dairy producer due to more inseminations, increased calving interval and increased culling rates (de Kruif, 1977 and Bartlett et al., 1986). Repeat breeding has been defined as failure to conceive from 3 or more regularly spaced services in the absence of detectable abnormalities (Zemjanis, 1980). Although there are many causes and factors of repeat breeder in dairy cow, endometritis has been described as the most common cause of the case (Sagartz and Hardenbrook, 1971; LeBlanc et al., 2002; Gilbert et al., 2005 and Ahmadi and Dehghan, 2007). Affected cows were 30\% less likely to become pregnant at first service and $70 \%$ more likely to be culled for reproductive failure (LeBlanc et al., 2002).

Endometritis is an inflammation of the endometrial lining of the uterus with or without systemic signs. It is usually associated with 
postpartum bacterial infection of the uterus (Lewis, 1997 and Bondurant, 1999). Clinically, the challenge is to identify those cows that are truly at risk of impaired fertility, in the hope that treatment can be administered to correct the problem.

The incidence and impact of clinical and subclinical endometritis in the postpartum period has been the objective of several studies (LeBlanc et al., 2002; Kasimanickam et al., 2004; Gilbert et al., 2005 and Williams et al., 2007). Clinical endometritis was characterized by a cervical diameter $>7.5 \mathrm{~cm}$ and the presence of purulent or mucopurulent vaginal discharge after 20 days postpartum. However, in a study by Hartigan et al. (1972) 50\% of the genital tracts obtained from an abattoir showed histological evidence of endometritis, yet only $12.5 \%$ showed gross lesions. Hence, it is likely that subclinical endometritis is a major contributor to the repeat breeder syndrome of bovine subfertility (Kasimanickam et al., 2004).

Veterinarians must identify and treat uterine diseases efficiently in order to limit their negative effects on fertility. Different treatment regimes, including intrauterine or parenteral antibiotics (e.g. penicillin, dihydrostreptomycin, tetracycline, and cephapirin) and PGF2 have been used to treat postpartum uterine disease (McDougall, 2001 and Ahmadi and Dehghan, 2007). However, it is difficult to determine the true treatment effect on reproductive performance when diagnostic criteria for uterine disease are not validated.

The most common means of diagnosis of endometritis is transrectal palpation of the uterus. However, this method is subjective and often fails to detect subclinical cases (LeBlanc et al., 2002). Therefore, recent studies have focused on a more sophisticated diagnostic tool of endometrial alterations beyond clinical signs of endometritis (Smith et al., 1998 and Sattler and Furll, 2004).

Serum level of some enzymes as creatine phosphokinase (CPK) and aspartate aminotransferase (AST) in relation to endometritis has been subjected to a number of studies. The CK is a muscule-specific enzyme that plays an important role in the energy transfer. It catalyzes the conversion of creatine to creatine phosphate with the conversion of ATP to ADP and release of energy (Galitzer and Oehme, 1985). There are relatively few studies about $\mathrm{CK}$ in cows. The $\mathrm{CK}$ activity is especially high in tissues with high-energy transfer such as muscle and brain. In the inner organs, there are also high activities of CK, with the CK activities in the uterine tissue being the third highest after skeletal and cardiac muscles (Sattler and Furll, 2004). In some studies, 
significant CK activity was reported in the serum of pregnant women and guinea pigs before and after delivery. This was explained by the higher metabolic demand in late pregnancy and the mechanical and metabolic stress of the uterine tissue (Clark et al., 1994 and Abramov et al., 1996). Hormonal stimulation of the smooth muscles of bovine uterus had resulted in significant elevation of the CK serum activity (Iyengar et al., 1980).

The aspartate amino transferase (AST) is considered a muscle and liver-specific enzyme in cattle. The highest AST activities were recorded in case of damage of liver followed by skeletal muscles and heart muscles (Medway et al., 1974). However, AST is not liver-specific enzyme as it found in most tissues. Previous studies had recorded significant AST activity in many clinical cases that involve the bovine uterine tissues as puerperal disorders in dairy cows, uterine torsion and endometritis (El-Din Zain et al., 1997, Oliveira et al., 1998 and Amer et al., 2008). It was found that cows with highly abnormal puerperium 3 weeks postpartum had higher AST activities than healthy cows at the same postpartum period (Oliveira et al., 1998).

Obviously, there is an apparent connection between the activity of CPK and AST enzymes and uterine affections. Therefore, the current study aimed to evaluate the variation of CPK and AST activities in relation to clinical and sub-clinical endometritis. Moreover, the influence of conventional treatment of endometritis with the subsequent conception on the activity of CPK and AST activities was also investigated. The ultimate goal is to assess the possibility of using these enzymes as sensitive parameter for evaluation of the status of uterine wall and the extent of its affection.

\section{MATERIALS and METHODS}

Animals: The current study was conducted between December 2007 and July 2008 on suspected repeat breeder mixed breed cows that were presented to the Veterinary Clinic, Department of Theriogenology, faculty of Veterinary Medicine, Assiut University. All presented cows failed to conceive and came into heat regularly every 20-21 day for at least 3 successive times. Thorough clinical examination of tested cows revealed no any visible abnormal clinical manifestations related to liver disease.

Clinical examination: All suspected cows were subjected to thorough clinical examination. During which, suspected cows were first inspected 
for the presence of fresh discharge on the vulva, perineum, or tail. If discharge was not visible externally, cows were examined vaginoscopically. The vaginoscope was inserted into the vagina up to the level of the external os of the cervix. Inspection of the cervix and vagina was performed with illumination from a penlight. The nature of discharge was recorded (clear mucus with or without flecks of pus; muco-purulent or purulent discharge). Following inspection and vaginoscopy, transrectal palpation of the reproductive tract was performed. Moreover, all suspected cows were ultrasonographically examined by using a $6 / 8 \mathrm{MHz}$ linear array transducer connected to Bmode ultrasound scanner (100 LC, Pie Medical, Masstricht, Netherland) for assessment of uterine echogenicity, the uterine thickness and uterine fluid.

Study design: Animals with pyometra at admission (uterine horn distended with fluid in the presence of a CL, diagnosed by palpation) or those with adhesions involving the internal genitalia were all excluded from the study. For the current study, 23 cows with endometritis were selected and sub-divided into 2 group based on the clinical findings according to Kasimanickam et al. (2006). Group 1 (G1, $\mathrm{n}=9$ cows), which included severely affected cows and with external and/or internal mucopurulent uterine discharge, thick uterine wall and enlarged cervix ( $<7 \mathrm{~cm}$ diameter). Group 2 (G2, $\mathrm{n}=14$ cows), which included mildly affected cows. By examination of their genitalia revealed the absence of external discharge, normal uterine wall, normal cervix diameter $(>5 \mathrm{~cm})$. In addition, 20 mixed breed cows were selected from local private farms of surrounding villages and subjected to clinical examination and proved healthy and free from endometritis and were used as a control group.

Treatment of affected cows: The suspected clinically and sub-clinically affected cows were subjected to one of intrauterine infusion of the following treatments: 1) Cephquenome $0.5 \mathrm{gm}$ antibiotic (Cobactan ${ }^{\circledR}$, Hoeschst Russel Vet., Turkey). The treatment was applied for 5 cows from G1 and 7 cows from G2. 2). For 4 cows from G1 and 7 cows from G2 intrauterine infusion using $30 \mathrm{ml}$ of Lugol's Iodine $2 \%$ was used (prepared by dissolving 40gm potassium iodide in 1000 distilled water then dissolved $20 \mathrm{gm}$ inorganic iodine). Treatments were repeated in some cases twice or three times at one week interval. The control healthy animals were left without treatment. Post treatment; all cows were observed for heat and were artificially inseminated by experienced inseminators. Pregnancy was diagnosed using trans-rectal Ultrasonography (US) between 27 and 34 days and by rectal palpation 
between 40 and 90 days post-insemination for all treated and control cows.

Biochemical analysis: Blood samples without anti-coagulant were collected from studied cows for assessment of the serum activity of CPK (U/l) and AST (U/l) enzyme as well as total proteins (g/l), albumin (g/l), globulins $(\mathrm{g} / \mathrm{l})$ and $\mathrm{A} / \mathrm{G}$ ratio in both clinical and sub-clinical endometritis groups $(\mathrm{G} 1, \mathrm{G} 2)$ before treatment as comparison to that of healthy control group. In addition, blood samples were collected from conceived cows of G1 and G2 after treatment for assessment of the same parameters in comparison to that before treatment. The serum activity of CPK and AST enzymes were measured by kinetic method using standard testkits supplied by STANBIO Laboratory, Berne, TX. The serum levels of total proteins and albumin were determined colorometerically using commercial testkits supplied by QUIMICA CLINICA APLICADA S. A. (QCA), Amposta, Spain, while globulins level were calculated as the difference between total proteins and albumin (Latimer et al., 2003). All measurements were carried out using spectro UV-Vis RS digital spectrophotometer UV 2500, Labo Med, Inc., CA, USA.

Statistical analysis: The findings were expressed as the means \pm SD. Statistical analyses were performed by one-way ANOVA using the Statistical Package for the Social Sciences for Windows (SPSS, version 10.0, Chicago, IL, USA).

\section{RESULTS}

\section{Biochemical analysis findings}

A) Enzymatic activity of serum CPK and AST: The results of the current study revealed that, before treatment there were up to 10 folds and 3 folds significant increase $(\mathrm{P} \leq 0.001)$ in the activity of serum CPK and AST, respectively, in clinical endometritis group (G1) as compared to the control healthy group (Table 1, Figure 1). On the other hand, regarding the sub-clinical endometritis group (G2), up to 3 folds significant increase $(\mathrm{P} \leq 0.001)$ of $\mathrm{CPK}$ activity in sub-clinical endometritis group was recorded as compared to control healthy group. While non-significant change of the AST activity was recorded (Table 1, Figure 2).

After treatment and occurrence of conception, biochemical analysis revealed significant reduction $(\mathrm{P} \leq 0.001)$ of $\mathrm{CPK}$ activity in both clinical and sub-clinical endometritis group and AST activity in clinical 
endometritis group as compared to their activities before treatment (Table 1, Figure 2).

B) Proteingram: Significant elevations $(\mathrm{P} \leq 0.001)$ of serum total proteins and globulins concentration along with significant reduction $(\mathrm{P} \leq 0.001)$ of the $\mathrm{A} / \mathrm{G}$ ratio were recorded in the clinical endometritis group (G1) before treatment as compared to the healthy control group (Table 1, Figure 1). However, after treatment, significant reduction $(\mathrm{P} \leq 0.001)$ of total proteins and globulins and significant elevation $(\mathrm{P} \leq 0.001)$ of $\mathrm{A} / \mathrm{G}$ ratio were evidence as compared to that before treatment (Table 1, Figure 2). On the other hand, and regarding the subclinical endometritis group (G2), non-significant or hardly significant $(\mathrm{P} \leq 0.05)$ changes were recorded in the concentrations of serum total proteins, albumin, globulins and $\mathrm{A} / \mathrm{G}$ ratio in this group before treatment as compared to control healthy group (Table 1, Figure 1).

C) Conception rate: It was found that after using Cephquenome the conception rate in G1 and G2 was 60\% (3 from 5 cows) and 85.7\% (6 from 7 cows) respectively. The resulted conception rate after application of Lugol' Iodine in G1 and G2 was 50\% (2 from 4 cows) and 51.14\% (4 from 7 cows), respectively. In control, all animals were conceived.

D) Ultrasonographic examination: Ultrasonographic diagnosis of endometritis using echogenicity of the sonographic image was useful for the $\mathrm{G} 1$ animals but had no diagnostic value for $\mathrm{G} 2$ cows. The image appeared hyperechogenic with hyperechogenic flakes in the endometrium. The endometrial thickness in G1 was $12.8 \pm 0.8 \mathrm{~mm}$ and in G2 was $6.7 \pm 0.9 \mathrm{~mm}$ and the difference was highly significant. $(\mathrm{P} \leq 0.001)$. There were no significant differences between the endometrial thickness in $\mathrm{G} 2$ and control group $(6.7 \pm 0.9$ vs. $6.2 \pm 1.1$ $\mathrm{mm}$ ) (Figure2). Five cows in G1 showed endometrial fluid with hyperechogenic flakes, the diameter of the uterine lumen was $3.6 \pm 0.8$ $\mathrm{mm}$ and it was recorded no endometrial fluid inside the uterus in G2 and control animals except if the cow was examined during estrus period (2 cows). 
Table 1: Mean and SD of biochemical parameters in clinical and sub-clinical endometritis groups before treatment as compared to healthy control and same groups after treatment.

\begin{tabular}{|l|c|c|c|c|c|}
\hline \multirow{2}{*}{$\begin{array}{c}\text { Biochemical } \\
\text { parameters }\end{array}$} & $\begin{array}{c}\text { Control group } \\
(\mathrm{n}=20)\end{array}$ & \multicolumn{2}{|c|}{ Before treatment } & \multicolumn{2}{c|}{ After treatment } \\
\cline { 3 - 6 } & & $\mathrm{G} 1(\mathrm{n}=9)$ & $\mathrm{G} 2(\mathrm{n}=14)$ & $\mathrm{G} 1$ & $\mathrm{G} 2$ \\
\hline $\begin{array}{l}\text { CPK activity } \\
\text { level (U/l) }\end{array}$ & $241.8 \pm 50.0$ & $2251 \pm 510.0^{* * * a}$ & $605.2 \pm 155.0^{* * * a}$ & $413.9 \pm 69.2^{* * * b}$ & $322.4 \pm 65.0^{* * * b}$ \\
\hline $\begin{array}{l}\text { AST activity } \\
\text { level (U/l) }\end{array}$ & $91.5 \pm 15.5$ & $297.8 \pm 57.7^{* * *} a$ & $107.2 \pm 24.4$ & $114.3 \pm 22.2^{* * * b}$ & $107.8 \pm 30.1$ \\
\hline TP (g/l) & $72.5 \pm 4.9$ & $95.5 \pm 6.6^{* * * a}$ & $73.9 \pm 5.7$ & $79.2 \pm 6.4^{* * * b}$ & $68.5 \pm 5.5$ \\
\hline Alb. (g/l) & $34.5 \pm 2.7$ & $30.9 \pm 2.8$ & $30.7 \pm 3.4$ & $29.9 \pm 2.2$ & $30.3 \pm 3.8$ \\
\hline Globs.(g/l) & $37.9 \pm 3.9$ & $64.5 \pm 8.1^{* * * a}$ & $43.2 \pm 3.9^{* a}$ & $49.4 \pm 7.1^{* * * b}$ & $38.1 \pm 4.1$ \\
\hline A/G ratio & $0.9 \pm 0.1$ & $0.5 \pm 0.1^{* * a}$ & $0.7 \pm 0.1^{* a}$ & $0.6 \pm 0.1^{* b}$ & $0.8 \pm 0.1^{* b}$ \\
\hline
\end{tabular}

**** $(\mathrm{P} \leq 0.001),{ }^{*}(\mathrm{P} \leq 0.05)$.

${ }^{a}$ Significant changes in studied parameters in investigated group as compared to that of control group.

${ }^{b}$ Significant changes in investigated group after treatment as compared to that before treatment. 


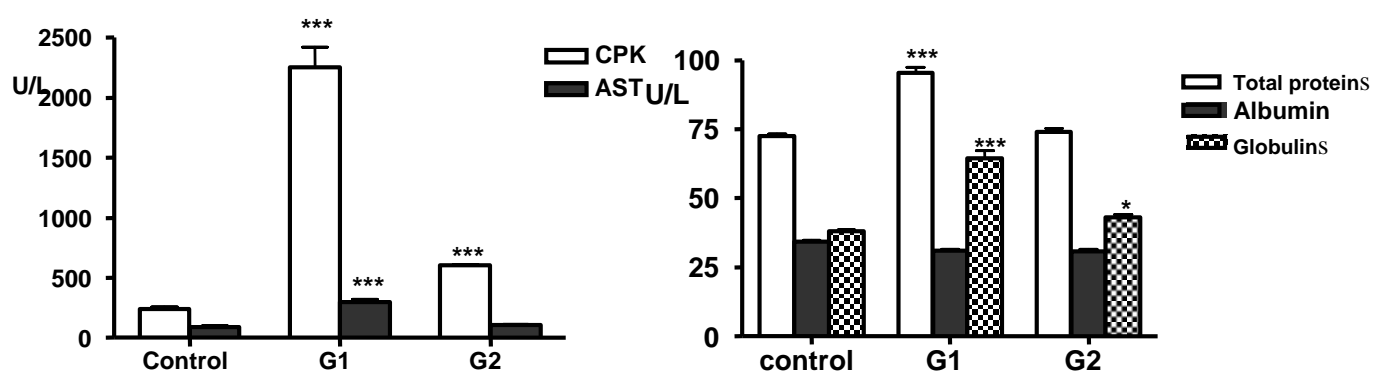

A

B

Fig. 1: Enzymatic activity of CPK and AST and protein profile values of clinical and subclinical endometritis groups before treatment as compared to healthy control group. $\mathbf{A}$, significant increase $(\mathrm{P} \leq 0.001)$ in CPK and AST activity in clinical endometritis group and significant increase $(\mathrm{P} \leq 0.001)$ of $\mathrm{CPK}$ activity in sub-clinical endometritis group as compared to control healthy group. B, Significant elevation $(\mathrm{P} \leq 0.001)$ of total proteins and globulins concentrations in clinical endometritis group as compared to the healthy control group.

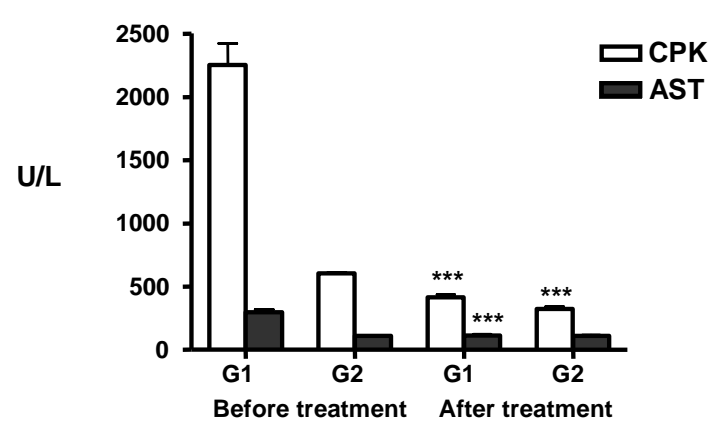

A

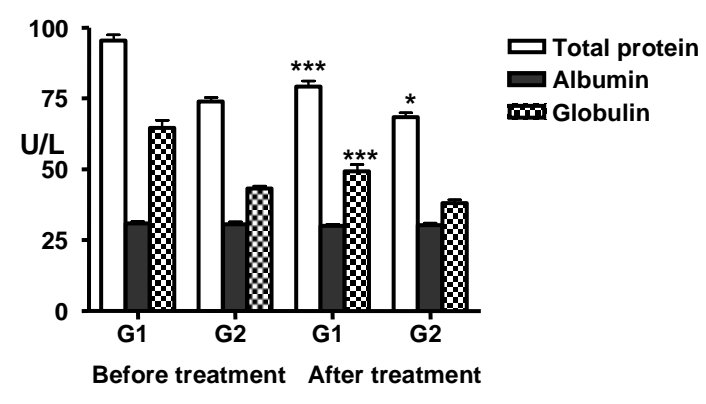

B

Fig. 1: Enzymatic activity of CPK and AST and protein profile values of clinical and subclinical endometritis groups after treatment as compared to that before treatment. A, significant reduction $(\mathrm{P} \leq 0.001)$ in $\mathrm{CPK}$ and AST activity in clinical endometritis group and significant reduction $(\mathrm{P} \leq 0.001)$ of $\mathrm{CPK}$ activity in sub-clinical endometritis group as compared same group before treatment. B, significant reduction $(\mathrm{P} \leq 0.001)$ of total proteins and globulins concentrations in clinical endometritis group as compared to the same group before treatment. 


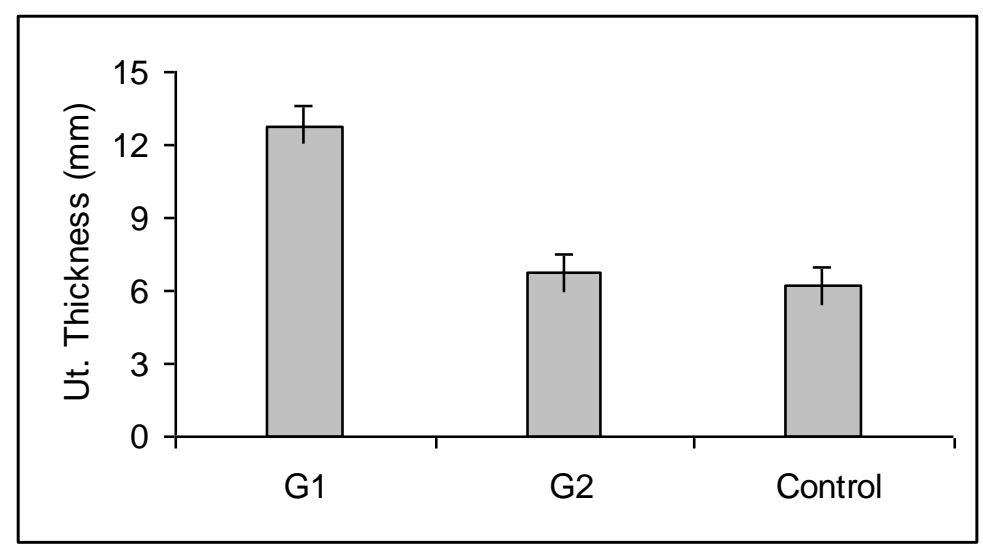

Fig. 2: Uterine thickness in the ultrasonographic image in G1, G2 and control.

\section{DISCUSSION}

Repeat breeder syndrome is a major source of economic waste in dairy herds. Clinically, the challenge is to identify those cows that are truly at risk of impaired fertility, in the hope that treatment can be administered to correct the problem. The commonly used method for diagnosing endometritis is transrectal palpation of the uterus. However, this method is subjective and often fails to account for the extent and variability of uterine affection or to have any association with reproductive performance (Lewis, 1997 and LeBlanc et al., 2002). For reproductive examinations before the breeding period to be of value, they must identify not only clinically affected cows, but also cows at increased risk of failure to become pregnant in a timely way (Ferguson and Galligan, 1999). The activities of muscular tissue-related enzymes, CPK and AST, were evaluated in the current study in a trial to reach a more sensitive diagnostic tool that could reflect the presence and the extent of uterine tissue damage. In the present study, investigated cows with suspected endometritis were classified into 2 groups based on transrectal palpation of the uterus, vaginoscopical examination of vagina and cervix and ultrasonographical examination of the uterus and ovaries. The first group (G1) included 9 severely affected cows as described in the result section and assigned as clinical endometrits group, while the second group (G2) included 14 mildly affected cows and assigned as sub-clinically endometritis group as described elsewhere (LeBlanc et al., 2002). 
Current results revealed significant elevation of CPK activities in cow with endometritis as compared to healthy cows, which is in accordance with previous studies that revealed high CK activities especially in the placenta and endometerium (Payne et al., 1993). The elevated enzyme activitiy could be attributed to the destruction of cells in the uterine wall that occur during endometritis (Sattler and Furll, 2004). Interestingly, the level of the elevated serum CPK activity was varied according to the severity of endometritis, as it reached up to 10 fold increase in case of severely affected cows (clinical endometrits) comparing to only 3 folds increase in mildly affected cows (sub-clinical endometritis). This variation of the enzyme activity is obviously correlated with the degree of uterine tissue damage (Sattler and Furll, 2004). These findings indicate that the activity of serum CPK enzyme is greatly influenced by the damage degree of uterine tissue. This was supported by the significant reduction of the level of this enzyme close to the normal levels after treatment of endometrits and conception of the cows.

Regarding AST enzyme, significant elevation up to 3 folds of its activity was recorded only in severely affected cows, while nonsignificant change was recorded in mildly affected ones. These findings could indicate that the change of AST activity was not a direct response to uterine tissue damage, but secondary to severe endometritis. This could be explained by what was proposed previously that only during severe endometritis the endotoxins absorbed from the uterine lumen could play an important role in skeletal muscle damage and hence the elevation of AST activity (Smith et al., 1998 and Sattler and Furll, 2004). This proposal was supported by the simultaneous significant increase of globulins concentration only in severely affected cows, which is believed to be due to the effect of the absorbed endotoxins as well.

The echogenicity of the picked ultrasonographic images, Ultrsonographic measured endometrial thickness and uterine fluid may be useful for the diagnosis of clinical endometritis but not precise for diagnosis of subclinical endometritis, because there were no significant differences between the control group and those with subclinical endometritis. Because measures of endometrial thickness and uterine fluid can be easily influenced by the stage of the cycle and the location of the uterine horn the ultrasonographic measurements are not precise. This results in agreement with that reported by Kasimanickam et al. (2004) and Barlund et al. (2008). 
As conclusion, in apparently healthy cows and with no obvious muscular damage, hypocalcemia or liver diseases, the activity of serum CPK and AST enzymes can be used as a screening parameters for diagnosis of endometrits especially in sub-clinical cases.

\section{REFERENCES}

Abramov, Y.; Abramov, D.; Abrahamov, A.; Durst, R. and Schenker, J. (1996): Elevation of serum creatine phosphokinase and its MB isoenzyme during normal labor and early puerperium. Acta Bstet. Gynecol. Scand. 75, 255-260.

Ahmadi, M.R. and Dehghan, S.A. (2007): Evaluation of the Treatment of Repeat Breeder Dairy Cows with Uterine Lavage plus PGF2a, with and without Cephapirin. Turk. J. Vet. Anim. Sci. 31, 125129.

Amer, H.A.; Hashem, M.A. and Badr, A. (2008): Uterine Twisting During Pregnancy in Buffaloes: Relatioship Between Clinical Findings and Biochemical Indices. Journal of Applied Biological Sciences, 2 (2): 31-39.

Barlund, C.S.; Carruthers, C.L.; Waldner, C.L. and Palmer, C.W. (2008): A comparison of diagnostic techniques for postpartum endometritis in dairy cattle. Theriogenology. 69: 714-723.

Bartlett, P.C.; Kirk, J.H. and Mather, E. (1986): Repeated insemination in Michigan Holtsein Fresian cattle: Incidence, descriptive epidemiology and estimated economic impact. Theriogenology. 26: 309-322.

Bondurant, R.H. (1999): Inflammation in the bovine female reproductive tract. J. Dairy Sci. 82 (Suppl. 2): 101-110.

Clark, J.F.; A.V. Kuznetsov, A.V.; Khuchua, Z.; Veksler, V.; VenturaClapier, R. and Saks, V. (1994): Creatine kinase function in mitochondria isolated from gravid and non-gravid guinea pig uteri. FEBS Lett. 347, 147-151.

De Kruif, A. (1977): Repeat breeders - A survey and study of cows upon fourth insemination. Bovine Practitioner, 11: 6-8.

El-Din Zain, A.; El-Ballal, S.S. and Shehata, S.H. (1997): Alkaline phosphatase and transaminases activity in uterine flushing of buffalo-cows affected with endometritis. Buffalo J., 13,1: 95102. 
Ferguson, J.D. and Galligan, D.T. (1999): Veterinary Reproductive Programs. Pages $131-137$ in Proceedings of $32^{\text {nd }}$ Annual Convention of American Association of Bovine Practitioners, Nashville, TN, USA.

Galitzer, S.J. and Oehme F.W. (1985): Creatine kinase isoenzymes in bovine tissue. Am. J. Vet. Res. 46, 1427-1429.

Gilbert, R.O.; Shin, S.T.; Guard, C.L.; Erb, H.N. and Frajblat, M. (2005): Prevalence of endometritis and its effects on reproductive performance of dairy cows. Theriogenology, 64:1879-88.

Hartigan, P.J.; Murphy, J.A.; Nunn, W.R. and Griffin, J.F. (1972): An investigation into the causes of reproductive failure in dairy cows: Intra uterine infection and endometrial histopathology in clinically normal-repeat breeder cows. Irish Vet. J., 26: 245247.

Iyengar, M.R.; Fluellen, C.E. and Iyengar, C.W. (1980): Increased Creatine kinase in the hormone-stimulated smooth muscle of of the bovine uterus. Biochem. Biophys. Res. Commun. 94, 948954.

Kasimanickam, R.; Duffield, T.F.; Foster, R.A.; Gartley, C.J.; Leslie K.E. and Walton J.S. (2004): Endometrial cytology and ultrasonography for the detection of subclinical endometritis in postpartum dairy cows. Theriogenology; 62: 9-23.

Kasimackam, R.; Cornwell, J.M. and Nebel, R.L. (2006): Effect of presence of clinical and subclinical endometritis at the initiation of Presynch-Ovsynch program on the first service pregnancy in dairy cows. Animal reproduction science, 95, 214-223.

Latimer, K.S.; Prasse, K.W. and Mahaffey, E.A. (2003): Proteins, Lipids, and Carbohydrates. In Veterinary Laboratory Medicine: Clinical Pathology, 4th ed. Ames, Iowa State University Press, pp. 162-192.

Le Blanc, S.J.; Duffield, T.F.; Leslie, K.E.; Bateman, K.G.; Keefe, G.P.; Walton, J.S. and Johnson, W.H. (2002): Defining and diagnosing postpartum clinical endometritis and its impact on reproductive performance in dairy cows. J. Dairy Sci. 85: 2223-2236.

Lewis, G.S. (1997): Uterine health and disorders. J. Dairy Sci. 80: 984994. 
McDougall, S. (2001): Effect of periparturient disease on the reproductive performance of New Zealand dairy cows. NZ Vet J; 49: 60-67.

Medway, W.; Prier, J.E. and Wilkinson, J.S. (1974): A Textbook of Veterinary Clinical Pathology. The $2^{\text {nd }}$ ed. Williams \& Wilkinson Co. Ballimore, pp. 72.

Oliveira, M.A.; Lima, P.F. and Paes Barreto, M.B. (1998): Use of AST, total bilirubin and total cholesterol as parameters for the early diagnosis of puerperal disorders in dairy cows. Ciencia Veterinaria Nostropicos 1(1): 55-59.

Payne, R.M.; Friedman, D.L.; J.W. Grant, J.W.; Perryman, M.B. and Strauss, A.W. (1993): Creatine kinase isoenzymes-highly regulated during pregnancy in rat uterus and placenta. Am. J. Physiol.265, 624-635.

Sagartz, J.W. and Hardenbrook, H.G. (1971): A clinical, bacteriologic, and histologic survey of infertile cow. J. Am. Vet. Med. Assoc., 158: 619-622.

Sattler, T. and Furll, M. (2004): Creatine kinase and Aspartate Aminotransferase in Cows as indicators for endometritis. J. Vet. Med. 51, 132-137.

Smith, B.G.; Donovan, G.A.; Risco, C.A.; Young, C.R. and Stanker, L.H. (1998): Serum haptoglobin concentration in Holstein dairy cattle with toxic puerperal meteritis. Vet. Rec. 142, 83-85.

Williams E.J.; Fischer D.P.; Noakes, D.E.; England, G.C.; Rycroft A. and Dobson, H. (2007): The relationship between uterine pathogen growth density and ovarian function in the postpartum dairy cow. Theriogenology, 68: 549-59.

Zemjanis, R. (1980): "Repeat Breeding" or conception failure in cattle. In: Morrow DA., editor. Current Therapy in Theriogenology. $2^{\text {nd }}$ ed. W.B. Saunders, Philadelphia, PA;. pp. 205-213. 